Prof. D.F. Tolmie

University of the

Free State, South Africa.

ORCID: http://orcid.

org/0000-0002-4804-

3523

DOI: http://dx.doi.

org/10.18820/23099089/

actat.v40i1.1

ISSN 1015-8758 (Print)

ISSN 2309-9089 (Online)

Acta Theologica 2020

40(1):1-5

Date published:

17 June 2020

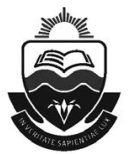

Published by the UFS

http://journals.ufs.ac.za/index.php/at

(C) Creative Commons

With Attribution (CC-BY)

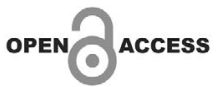

\section{INTERVIEW: \\ KEES WAAIJMAN}

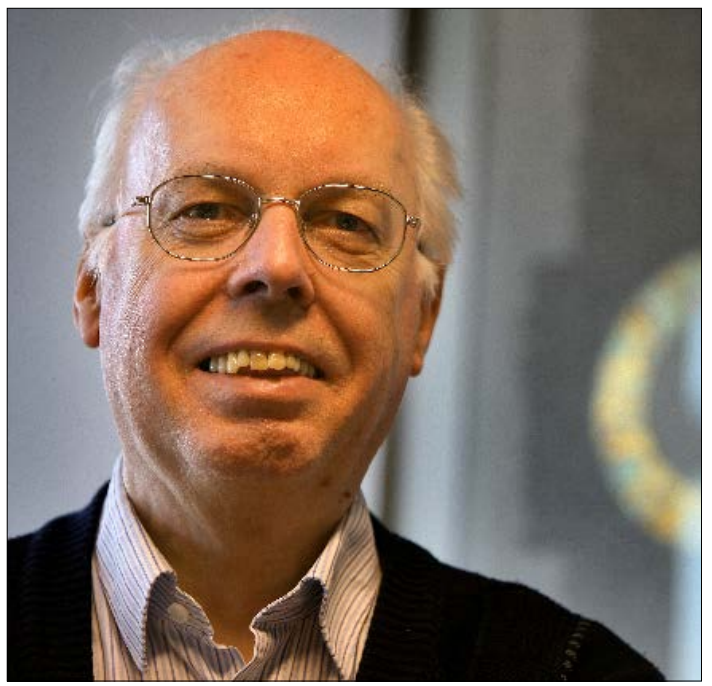

On 17 October 2019, Prof. Kees Waaijman delivered a guest lecture at the Faculty of Theology and Religion of the University of the Free State, Bloemfontein. He was asked to speak about his search for, and research on spirituality. Francois Tolmie interviewed him afterwards.

FT: You summarised your journey with spirituality in terms of seven key events in your life. Tell us about the first two.

KW: It all began roughly sixty years ago, in the 1960s, when I entered the Carmelite Order in Boxmeer. We prayed the whole of the Psalter - all 150 psalms - together every week, in Latin. I felt as if I was being plunged into the Psalms, an experience that shocked and overwhelmed me. It is difficult to explain exactly what happened to me, but in praying the Psalter I experienced strength, presence and beauty in an intimate way. I was fortunate in that I had received a 
good training in Latin at the gymnasium and I could thus understand what I was praying in Latin. As I prayed the Psalter together with the others, I experienced and understood them in a sort of first-hand way, directly, and this experience touched my life. It was not so much a grasping of all the detailed aspects of the Psalter, but rather an experience of immersing myself into the atmosphere of the Psalter. If felt as if I was born for the Psalter, and as if the Psalms were written for me! They opened my heart and widened my horizon.

An important event in my journey was when I continued my Carmelite formation in Dordrecht: A three-year course in philosophy. There, the teachers trained me in phenomenology and dialogical thinking. In the case of phenomenology, I was introduced to influential scholars such as Husserl, Heidegger and, in the case of dialogical thinking, to the works of Buber, Rosenzweig, and Levinas. The insights that I gained in this regard fitted very well with the way in which I experienced the atmosphere of the Psalter. However, it also worked the other way around. The Psalter revealed new dimensions of what I would call a poetic phenomenology, in which the unfolding of the divine-human relationship started to take a central position in my thinking. These two approaches phenomenology and dialogical thinking - later came together in my major work on spirituality, Spirituality: Forms, foundations, methods.

FT: The third important event was your four years of theological studies. You referred to this as a "clash". In what sense did you mean this?

KW: I continued my studies in Merkelbeek at the Carmelite Seminary, where I studied theology for four years. I experienced my introduction to theology as a "clash", albeit a "soft clash". Although the professors were quite good and knew their subjects well, and the theology that they taught was quite new nouvelle théologie - I nevertheless experienced the theological language as something strange. It did not fit in with the way in which I understood the Psalter, and I also experienced a clash between what I knew about phenomenology and dialogical thinking and what was taught at this seminary. Fortunately, the seminary had an open atmosphere and I thus started on my own journey with the Psalter. I studied the old versions of the Septuagint and the Vulgate, as well as the modern translations of the Psalter. I also spent much time on issues of semantics, particularly the study and translation of key terms in the Psalter. Aspects in my theological training that I did find helpful were the concepts of experience and contextuality, and the importance of history. Furthermore, the notion of sensus fidelium - the importance of the sensitivity of lay people in the field of faith and belief - started to appeal to me.

\section{FT: Your studies at Nijmegen constituted the next important event?}

KW: I began my postgraduate studies in Systematic Theology under Schillebeeckx, at Radboud University in Nijmegen. I wrote my dissertation 
under the guidance of Ephraem Hendricks. The theme of my dissertation was "The mysticism of $I$ and Thou". During the four years that I spent on this work, my dialogical thinking became more mature, as is hopefully illustrated in this work, which was defended in 1976. During this time, my research on the Psalter still continued. I studied modern Hebrew in Jerusalem, and Jewish mysticism at the Hebrew University.

FT: The Titus Brandsma Institute for Spirituality forms a very important part of your life. You indicated this as the fifth event that shaped your research.

KW: At first, my link with the Titus Brandsma Institute was informal. I joined them informally in 1968, but officially became a staff member in 1972. I worked on a project on the Psalter and published a commentary in 10 volumes on all 150 psalms. For this research project, I consulted secondary literature hundreds of publications - on the interpretation of the Psalter. Our new library at the Titus Brandsma Institute acquired around 400 copies of commentaries and studies on the Psalter, and by using this, together with what was available in the university library, I was able to get a picture of research in this field. In my research project, I tried to build a bridge between exegetes, for whom I had great respect - scholars such as Gunkel, Mowinckel, Kraus, Beyerlin, Seyhold, and so on. However, in spite of the great work that they did, it also felt to me as if they were closing the text by means of their reconstructions, and that more emphasis had to be placed on the role of the reader.

\section{FT: You also got a position at Radboud University?}

$\mathrm{KW}$ : I regard this as the sixth important event in my journey with spirituality. I became a member of the Board of the Titus Brandsma Institute. I spent $50 \%$ of my time on this; the other $50 \%$ I spent on spirituality as professor at Radboud University, where I was appointed in 1985. During this phase of my life, I discovered the need for a methodology for studying spirituality, and $I$ thus devoted much time to this. Meanwhile our library at the Titus Brandsma Institute had grown to around 85000 volumes on spirituality, which made my research in this regard much easier. In my endeavour to develop a methodology for studying spirituality, I intentionally opted for an interdisciplinary angle - something that was challenged by the work done at the Titus Brandsma Institute as this institute functioned in a multidisciplinary way. My research culminated in my book Spirituality: Forms, foundations, methods. The Dutch version was published in 2000 (five editions have been printed thus far), and the English version, translated by John Vriend, appeared in 2002. It has also been translated into German, Italian, Spanish and Russian. 
FT: The last eight years you have again been busy with the Psalter - the seventh key event in your journey with spirituality. What are you researching now?

KW: Yes, I am currently again researching the Psalter, now on a full-time basis. My current interest may be summarised in terms of a triangle - a threefold focus - on liturgy, spirituality and the Psalter. Starting with liturgy. Liturgy is a broad field. I am focusing on a specific part of the liturgy, the socalled "liturgy of hours". In this liturgy, the Psalter is the main course. Over the past fifty years, I have worked on a specific form of this liturgy. Mostly, the liturgy of hours is arranged in a monastic way. As Carmelites, we live in the city, not in an abbey, and we prefer to pray together with lay people. My intuition is that the perspective of liturgy may be an important contribution to the Psalter studies and the study of spirituality. Liturgy makes us aware of the deepest layer of the Psalter as prayer, prayer out of the depths - after all, the exile is the cradle of the Psalter. Spirituality may learn from the Psalter that prayer is not simply saying prayers, but becoming aware of God's presence, being involved in a process of divine human transformation. But also, the other way around; spiritual liturgy has taught me that, by praying the Psalter regularly, an inner space in my soul has grown, resistant against destruction.

FT: One of the aspects that you highlighted at the guest lecture is the notion of the Psalter as a kind of a mental space. What do you mean by this?

By regularly praying the Psalter over the last decennia, the Psalms have become for me a space for meditation and reflection, a kind of inner identity. Three aspects are important in this regard.

First, the divine name Yahweh. My study of this issue started more or less 50 years ago. I have constantly been studying the meaning of the name Yahweh. I was not content with merely replacing or substituting it with other words or concepts such as Adonaj, ha Shem, Kadōsj, and so on. In particular, I meditated on the meaning of the concept hajah, "to be" or "to be with" - the notion that is highlighted when the Name was revealed in Exodus. Eventually, $I$ received the insight that the best way to grasp the meaning of the name Yahweh is to understand it as "Wezer" (in Dutch), or "Be-er" (in English). After years of study, I published the book Betekenis van de naam Jahwe (1984). In this book, I included a complete list of literature, as well as discussions of the reception of the Name in Jewish mysticism, and how the Name functioned as the centre of my meditation and innermost prayer.

Secondly, the Name in the Psalter helped me understand the nature of ha ish ("man") - in particular, man as a responsive human being, someone who can be moved directly by ha Shem, someone who may be characterised by chesed and tsedekah. I gained a picture of "man" as a "man with a heart", heart being the place where all human layers find their unity, but at the same time also an unfathomable, infinite depth. Furthermore, I learnt that "man" also 
has a "soul" - an inner space of longing and remembering, both vulnerable and vital, with needs and passions.

Thirdly, the Psalter gave me the vocabulary for prayer. Of the many things that I could mention, I highlight only two. The Psalter taught me chaphats - delight, enjoyment, pleasure. It taught me a deep sensitivity for saying willingly: "Here I am, teach me; lead me in your goodness." It thus has to do with the inner movement of one's will, to be in awe and wondering, stillness and humility, in the presence of the Name. Secondly, it taught me to hagah - "to murmur" - to speak softly or almost inaudibly in response to the guidance of Be-er. From this perspective, the Psalter became to me a religious textbook, a book to meditate on, to learn from, and to interiorise. 